\title{
婎娠回数と歯牙の健康度との関係
}

\author{
九州大学衛生学教堂 (主任·水舅治夫 教授) \\ 九州䨑科大学衛生学教室 (主任 荷宮 交夫 教涭)
}

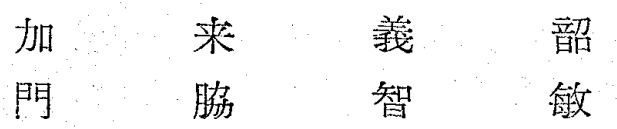

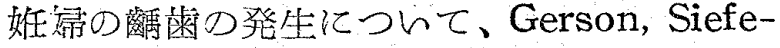
rt, Liesegang, Ziskin, Hottelin, Bill, Kinn-

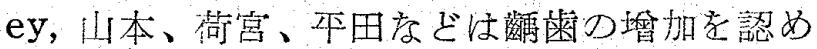
ている。Hoffstoroen, Siefert, Schwidt など

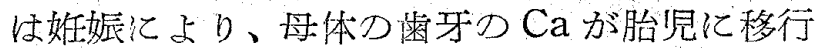

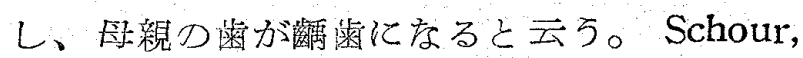
Robinson, Burket などは婎娠中佂牙のCaが 取り土られるということはなく、Deakins，Looby は実験によつて婎娠中でも、歯牙の学化 的組成社変化し疼んこと老証明し、授乳当同様

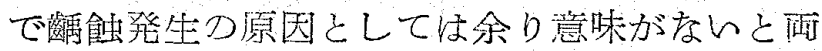

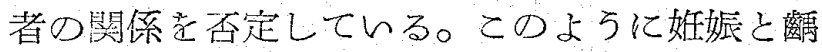
蒋已の関係について種々云われている。

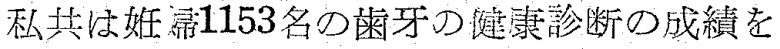
得をので、娃娠により歯牙つ徤康虔（D.M.F.

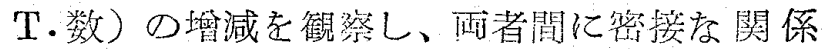
のることを認好を。成績の概要を発表する。

\section{I 資料と觀測方法}

本研究に用いた材料は、鹿児島県川内市保健所力昭 “和30年度に取扱つた婎婦である。菡牙の䛦断な同保健 所料科が扱つたものである。

観察方法统年代至20才代(20２9才)と30才代（30～ 39才)に区別し、各年代别に燋娠回数を調べた。歯牙 はD、M、F、T、を調ベた。即方、Dは人シ笨、Mは

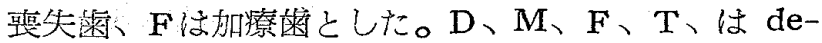
cayed + missing + filled teeth を路したものである。

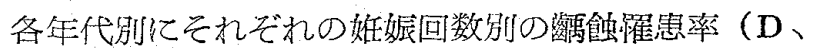
$\mathrm{M} 、 \mathrm{~F} 、 \mathrm{~T} 、)$ と、平均 $\mathrm{D} 、 \mathrm{M} 、 \mathrm{~F} 、 \mathrm{~T} 、$ 数觉比較 to

\section{II 成 績}

1. 年代另妵娠回数
調查資料 1153 名の 20 ,30才代の炸妮回数计表 1 の如 く、20才代が1.74回、30才代か3.37回で、明かに30代 が多い。

表 1 年代别婎桭回数

\begin{tabular}{|c|c|c|}
\hline 坟浱回数 & $20 \sim 29 才$ & 30 - 39才 \\
\hline 1 & 221 & 60 \\
\hline 2 & 132 & 106 \\
\hline 3 & 78 & 225 \\
\hline 4 & 19 & 182 \\
\hline 5 & & 97 \\
\hline 6 & & 21 \\
\hline 7 & & 12 \\
\hline 平䏛 & $1.74(\sigma=0.93)$ & 3. $37(\sigma=1.30)$ \\
\hline
\end{tabular}

2. 薑蝕䍜患率

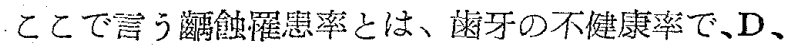

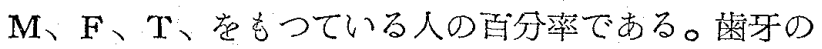

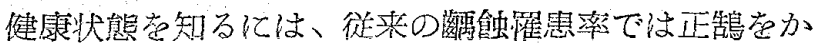

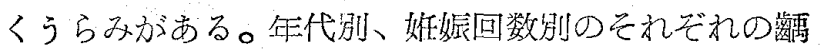
蝕羅患率は表 2、図1の如くである。

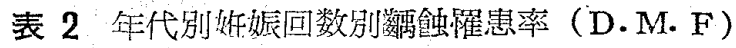

\begin{tabular}{|c|c|c|c|c|c|c|}
\hline \multirow{2}{*}{$\begin{array}{l}\text { 新脤 } \\
\text { 国数 }\end{array}$} & \multicolumn{3}{|c|}{20 ～29才 } & \multicolumn{3}{|c|}{30 〜 39才 } \\
\hline & 人䝿 & 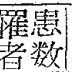 & $(\% \mathrm{P} \pm \mathrm{m} \%)$ & 人員 & 䋳思 & $\%(\mathrm{P} \pm \mathrm{m} \%)$ \\
\hline 1 & 221 & 184 & $83.26 \pm 2.51$ & 60 & 57 & $95.00 \pm 2.81$ \\
\hline 2 & 132 & 116 & $87.88 \pm 2.84$ & 106 & 100 & $94.34 \pm 2.24$ \\
\hline 3 & 78 & 72 & $92.31 \pm 3.01$ & 225 & 217 & $96.44 \pm 1.23$ \\
\hline 4 & 19 & 15 & $78.95 \pm 9.35$ & 182 & 172 & $91.76 \pm 2.03$ \\
\hline 5 & & & & 97 & 95 & $95.88 \pm 2.01$ \\
\hline 6 & & & & 21 & 19 & $90.48 \pm 6.40$ \\
\hline 7 & & & & 12 & 11 & $91.67 \pm 8.35$ \\
\hline 計 & 450 & 387 & $86.00 \pm 1.56$ & 703 & 669 & $95.16 \pm 0.81$ \\
\hline
\end{tabular}




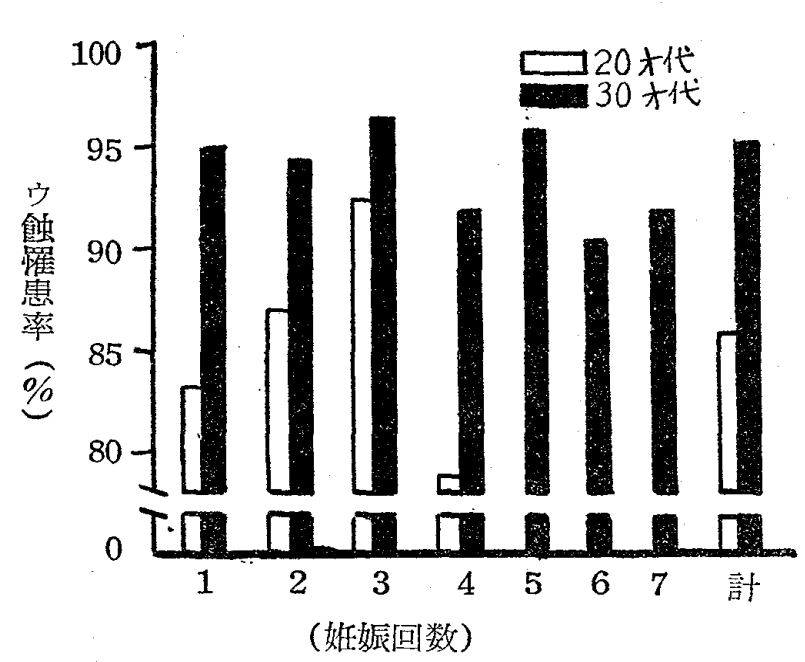

図 1 年代別姙浱回数別门蝕䍜患率

即ち20,30才代とも概して婎帳回数の增すに従い、 高率を示している。また各妊娠回数に尔いて、いずれ も30代か江代よりも高率を示す。これは增令により霜 牙の健康度の低下を示すものである。20才代と 30 才代 の総人員を見ると、20才代は86\%、30才代は95\%であ 万。

\section{3. 平均D.M.F.T.数}

20 , 30才代别に各妵娠回数得に平均D、M、F、T、 数は表 3、図20如し。

表 3 年代别婎娘回数别平均D.M.F.T数

\begin{tabular}{|c|c|c|c|c|}
\hline 婎娠 & & 〜 29才 & \multicolumn{2}{|c|}{$30-39$ 才 } \\
\hline 回数 & 人員 & $\begin{array}{c}\text { D.M.F.T.数 } \\
(\mathrm{M} \pm \mathrm{m})\end{array}$ & 人員 & $\begin{array}{c}\text { D.M.F.T.数 } \\
(M \pm m)\end{array}$ \\
\hline 1 & 221 & $3.59 \pm 0.08$ & 60 & $6.62 \pm 0.74$ \\
\hline 2 & 132 & $3.55 \pm 0.10$ & 106 & $7.57 \pm 0.58$ \\
\hline 3 & 78 & $4.65 \pm 0.42$ & 225 & $7.62 \pm 0.38$ \\
\hline 4 & 19 & $4.95 \pm 1.53$ & 182 & $7.34 \pm 0.41$ \\
\hline 5 & & & 97 & $8.08 \pm 0.68$ \\
\hline 6 & & & 21 & $6.67 \pm 1.03$ \\
\hline 7 & & & 12 & $4.84 \pm 2.61$ \\
\hline 計 & 450 & $3.80 \pm 0.17$ & 703 & $7.57 \pm 0.22$ \\
\hline
\end{tabular}

即ち、20才代は婎娠 I回のものが3.6で最も少く、回 数の増すにつれ增加し、4回には 5.0 となつている。 30才代も20才と同栐に回数の增加につれ增している。
20 ,30才代の資料総計では20才代に3.8,30才代に7.6で 30才代に明かに堌加が兒られる。

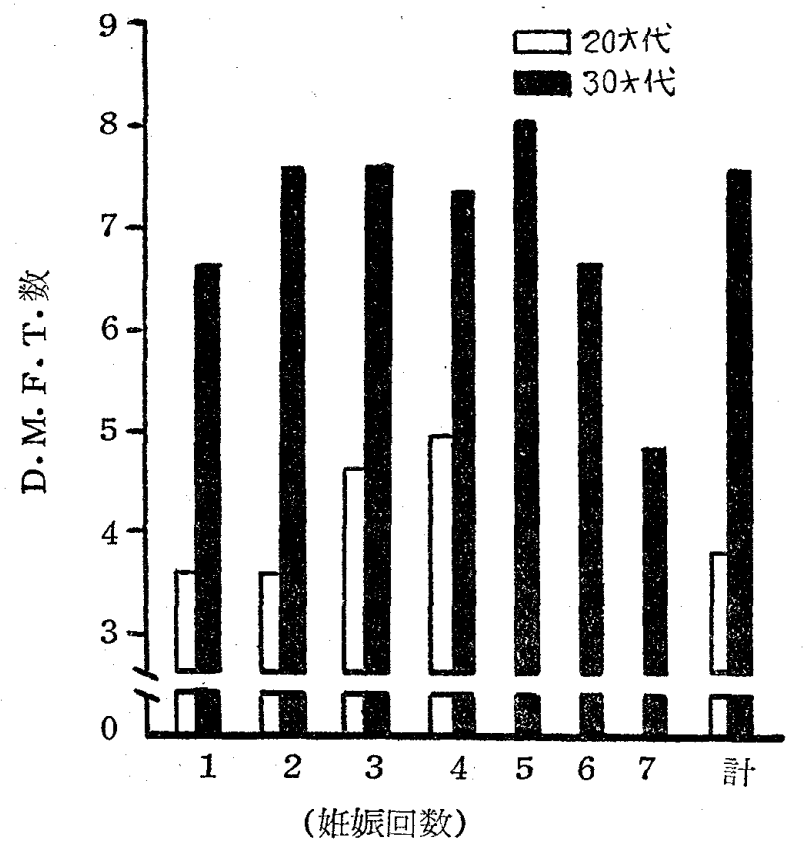

図 2 任代別姙娠回数别D.M.F.T.数

\section{III 考按とむすび}

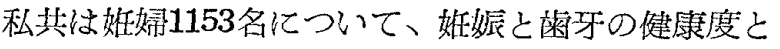
の関係を調べ、婊娠によつて雪牙の健康度の低下を来 すととを知つた。しの成因は婎娘そのものによるので なく、婎娠により起る合併症とも言うべき、内分必変 調、食物の㨝食、つわりによる睡液の酸度增加等力゙大 きく関与しているものと恩う。

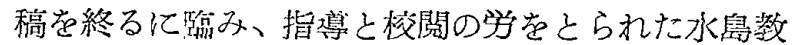
授、荷宮教授に深謝し、作せて本資料を提供された川 内保健所今泉やす子崡科衛生士に謝す。

\section{引用 文 献}

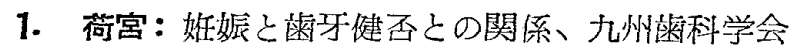
杂䧴誌、8巻、1.2号、昭 29.8

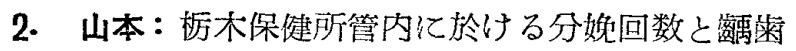

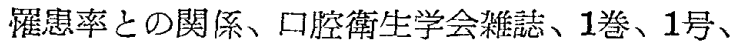
昭27.8

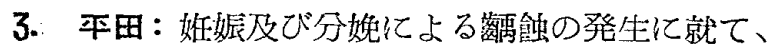
日本口腔科学会雑誌、4巻、2.3号、炤30.4 


\title{
THE TOOTH HEALTH RATE IN RELATION TO THE NUMBER OF PREGNANCY
}

by

\author{
Yoshiaki Kaku Tomotoshi Kadowaki
}

Department of Publi Health (Director : Prof. Dr. Haruo Mizushima)

Faculty of Medicine, Kyushu University, Fukuoka

Department of Hygienics (Director: Prof. Dr. Fumio Ninomiya)

Kyushu Dental College, Kokura.

Changes in the tooth health rate (D.M.F.T.) in relation to the increasing number of pregnancy were statistically examined on 1153 pregnant women, and the following conclusion was reached.

With the increasiug number of pregnancy the tooth health rate decreased. 